\title{
THE DILEMMAS OF OPPOSITION POLITICAL PARTIES IN SOUTHERN AFRICA
}

\author{
Bertha Chiroro
}

Bertha Chiroro is a Kellogg Foundation PhD Fellow and a Researcher at EISA PO Box 740 Auckland Park 2006, Johannesburg, South Africa

Tel:+27(0)11 482 5495; Fax:+27(0)11 4826163

e-mail: bertha@eisa.org.za

\begin{abstract}
This paper focuses on the dilemmas of opposition political parties in Southern Africa as they grapple with the double roles of democratising state and society and attempting to capture state power in an environment that has been ideologically hostile to the existence of opposition political parties. The supremacy of the liberation parties in the region makes it very difficult for the opposition political parties to rise to the challenge of offering alternative policy positions. The legitimacy enjoyed by the liberation parties causes ideological dilemmas for the opposition in its competing claims about the shape of economic and political governance. In extreme cases the opposition has to find strategies for responding to harassment, attacks on their supporters, media bias, misuse of state resources and the constraints of the dominant party system. Drawing on examples in Southern Africa the paper highlights the contradictions inherent in the perceptions of opposition parties in governance, their relative electoral weakness and the expectation that they should be the guardians of democracy in a multiparty system. The paper contends that the opposition in Southern Africa has been neglected in the governance debate. If Barrington Moore's maxim 'No opposition no democracy' is used to measure the levels of democratisation in Southern Africa it needs to be changed to 'No viable opposition no democracy in Southern Africa'.
\end{abstract}




\section{INTRODUCTION}

Viable opposition political parties and effective party systems are regarded as crucial to the building of democratic societies in Southern Africa. Since their emergence from colonial rule Zimbabwe, Namibia and South Africa have continued with multiparty politics, although the opposition is constantly muzzled in Zimbabwe. Tanzania, Zambia, Malawi and Mozambique, formally one-party states, have, since the 1990s, instituted multiparty politics. Only Swaziland remains a non-party state - party politics was banned by a royal decree on 12 April 1973 in the belief that the party political system is foreign to Africa and disruptive of the peace and stability of African nations (Mzizi 2005, p 4). Opposition leaders are therefore portrayed as despicable.

Opposition parties were regarded as enemies of the state in most of the oneparty states in Southern Africa before 1990. Even in countries such as Zimbabwe, which has had a multiparty constitution since independence, anyone who opposed the ruling party or the status quo was considered an enemy of transformation and anti-revolutionary. However, the advent of multiparty democracy in most Southern African countries in the 1990s pushed opposition parties into the limelight.

Post-1990 parties such as the Movement for Multiparty Democracy (MMD) in Zambia seemed to promise democratic change but did not live up to expectations once they were in government. It has been argued that the MMD regime has proven to be virtually as inept, corrupt and oppressive as the singleparty United National Independence Party (UNIP) dictatorship that preceded it (Venter 2003, p 324). However, a fiery campaign has been waged by opposition parties such as the Movement for Democratic Change (MDC) in Zimbabwe and the Civic United Front (CUF) in Tanzania to democratise the political space and to pressurise the incumbents to abide by the principles of liberal democracy.

Concurrently there has been both internal and external pressure for opposition parties and political parties in general to democratise their structures and activities in tune with their demands for democratisation. As a result, a number of donors and non-governmental organisations (NGOs) have been involved in supporting capacity building schemes for political parties and issues to do with inter-party dialogue, strengthening ties with civil society and intraparty democracy. Opposition parties are now faced with the double task of democratising the state and society as well as their internal structures. Using examples drawn from Southern Africa this paper seeks to show the extent to which opposition parties in the region have succeeded in those tasks and how they have sought to make government accountable and at the same time act as role models of democracy within their structures. The paper begins by locating 
opposition parties in the governance debate, and illustrates the opposition dilemma and the practical realities of opposition politics in Southern Africa.

\section{OPPOSITION POLITICAL PARTIES AND DEMOCRATIC GOVERNANCE}

The discourse on good governance emphasises the role of political parties as essential components of democratic regimes and key vehicles in the process of securing effective political representation, mobilising voters, organising government recruitment of elites, and shaping public policy (Webb 2005; Salih $2003, \mathrm{p} 4$ ). Opposition parties are lumped together with ruling parties in the governance discourse in Southern Africa, yet they need to be distinguished from ruling parties as they require more help.

It is argued that the technocratic interpretation of good governance, which is associated with the more administrative and managerial aspects, does not even consider the role of political parties (Hout 2003, p 261). However, the political interpretation of good governance, which insists on competitive democratic politics, does not highlight the role of opposition parties. Nonetheless, the existence of political parties competing for power within a framework of rules that guarantee equal chances for all is one of the fundamental characteristics of pluralist Western democracy. Parties play a key role in competitive elections; they help articulate, and express differing interests; and they give a voice to the people (Randall and Svasand 2002, p 5).

The emergence of a multiparty system in Africa is seen as an unavoidable consequence of the globalisation of democracy. Therefore, democratic rights such as freedom of association and freedom of speech are necessary components of democracy. In a multiparty system the opposition thus becomes crucial as it challenges the incumbent and provides horizontal accountability of government to the legislature.

the opposition is there both to monitor zealously and when need be criticize what government does and to present alternatives. This is especially important in the circumstances of democratic transition, when authoritarian precedents and habits may still significantly shape the behaviour of the ruling party.

Randall and Svasand 2002, p 7

In these circumstances preserving and enhancing the role of the opposition becomes critical to the democratic legitimacy of the whole political system. Most of the Southern African region grapples in varying degrees with issues to do with opposition politics. 
Donors have tended to support civil society and neglect political parties. Worse still, the nature of the socio-political development of political parties and liberation movements has resulted in opposition parties being totally neglected by the populace as well as by their governments. Most political parties in the region are not publicly funded and many of the opposition parties in Southern Africa have developed as a protest against the authoritarian tendencies of the incumbents. In such cases the logical thing for incumbent governments to do was to crush the opposition and restrict the environment in which they operate.

Except in the long-standing democracies of Botswana and Mauritius, the environment in Southern Africa has never been conducive to the growth of opposition politics. In the new democracies of South Africa and Namibia, the political environment is favourable but the opposition is still constituted on racial, regional and ethnic lines. In dominant party systems such as that in Zimbabwe every effort has been made to thwart opposition growth and the first-past-thepost (FPTP) electoral system has not favoured the growth of a strong opposition.

The realisation has now dawned on citizens and on local civil society organisations that while political parties in general are central to representative democracy and to the process of democratisation opposition parties are central to the consolidation of the process of democratisation. The quality of Southern African democracies now depends on the effectiveness of opposition parties in challenging the incumbent and its policies and providing alternative policies. Opposition parties aggregate and represent minority interests; they offer meaningful choices to the electorate and they are part and parcel of the nation-building exercise. They recruit alternative political leaders, they disseminate alternative political information, they provide voters with choices, and they manage conflicts of interest. If this role is not fully recognised and fully institutionalised in political structures the bulk of the Southern African democracies will remain fragile.

However, in Africa it is very difficult to find positive accounts of opposition political parties and their contributions to governance. African political parties are regarded as having low levels of institutionalisation and weak links to the societies they are supposed to represent (Randall and Svasand 2002, p 32). Opposition parties are described as 'Young, fragmented, ill organised, and dominated by individuals' (Van Cranenburgh 2003, p 205). Even in established democracies, as Webb (2005, p 633) asserts, parties are perceived in very negative terms and are said to be

self interested, untrustworthy, corrupt, challenged by interest groups, social movements, the media and the internet as forms of political participation or communication and incapable of providing accountable and effective governance. 
In Germany it is alleged that there is a crisis of party legitimacy and there is evidence to suggest that citizens are disillusioned with the motivations, true concerns and effectiveness of the parties. The evidence takes the form of declining electoral turnout, a decrease in the number of voters claiming strong partisan affiliations, and a striking reduction in party membership (Webb 2005, p 636).

The same could be said of Malawi, where the whole party system is in crisis - in the run up to the 2004 elections factions within parties emerged and eventually broke away and formed new parties. For example, the National Democratic Alliance (NDA) broke away from the United Democratic Front (UDF) and the Republican Party (RP) broke away from the Malawi Congress Party (MCP) and three more new parties - the People's Progressive Movement (PPM), the Malawi Forum for Unity and Development (MAFUNDE), and the People's Transformation Party (PETRA) - emerged as a reaction to declining constitutional and democratic standards (Patel 2005, p 28). While these parties have fragmented and mutated they have not added much value to the democratisation of Malawian politics.

Voter turnout throughout Southern Africa is declining except in Mauritius, which still boasts a minimum of 80 per cent since independence. Zimbabwe's Senate elections in November 2005 saw a record low voter turnout of 19,48 per cent (Results of the 2005 Senate Elections ZESN Report 2005) - a signifier of a general governance crisis, which seems to have affected the political parties, the citizenry and all other institutions of governance.

Opposition political parties appear to be more involved in personal squabbles and struggles for power than in focusing on their central role - to boost representative democracy and to make a difference to policy outcomes. The splits and power struggles and the lack of intra-party democracy within opposition political parties are bound to undermine their status among voters, especially in a region where opposition politics is not particularly popular. At the same time these parties are expected to maintain high moral and democratic standards and demand high standards from their governments. As Salih $(2005, \mathrm{p} 8)$ has asserted:

African opposition political parties, noting that governments do not often abide by the democratic rule, demand full compliance with the ethos of polyarchy. Unfortunately, once in government, opposition parties, also in common with most democracies in the world, revert to quasi-polyarchical and at times non-democratic tendencies. While it is very easy for opposition political parties to preach bold and rhetorical questions, once in power they find themselves constrained by a completely different policy environment - one where they have to respond to increasing demands with the meagre resources of underdeveloped economies. 
The outstanding example of this paradox is that of Zambia's former president, Frederick Chiluba, who is now embroiled in corruption charges and who tampered with the country's Constitution to bar former president Kenneth Kaunda from participating in the national elections. These undemocratic tendencies were further illustrated by his mobilisation of support for a third term, which was not constitutional.

\section{THE OPPOSITION DILEMMA}

Your business is not to govern the country but it is if you think fit to call to account those who govern it.

Gladstone (from Lavelle 2004)

Governments lose elections, oppositions do not win them

Tucker 2005

These two quotations highlight the dilemma of opposition political parties not only in Southern Africa but also in other political party systems. Opposition parties must choose either the competitive challenging role or the cooperative role, but, whichever they choose, it is still difficult for them to wrest power from the incumbent.

However, in established democracies the opposition have managed to overcome institutional, organisational and political barriers to their survival. Furthermore the role of the opposition in Western democracies is clearly defined as being to contribute to the formulation of policy and legislation by constructive criticism; to oppose government proposals it considers objectionable: seek amendments to government bills; and to put forward its own policies in order to improve its chances of winning the next general election (Government and opposition, UK Parliament document 2006, p 3).

In Southern Africa the opposition suffers from a legitimacy crisis and its role remains largely undefined - it is generally regarded merely to be a struggle for power. The incumbents also make an effort to delegitimise the opposition by using the media and public announcements.

For example, in Zimbabwe, even though the MDC has 41 seats in the legislature, the ruling party regards it as being sponsored by 'imperialists' and therefore as a front for British Prime Minister Tony Blair. In South Africa the Democratic Alliance, the official opposition, is increasingly viewed as reactionary and as representing white interests. In Mozambique Renamo is considered to have failed to graduate from a rebel movement to a political party representing broad interests. 
These perceptions serve to undermine the credibility of the opposition. However, they do not prevent the populace from judging the opposition by how effectively it presents a challenge to the ruling party and its success in keeping the government accountable. In South Africa there is very harsh criticism of the opposition both in the print media and from government officials. The country's Minister of Public Works and Administration, Geraldine Fraser Moleketi, was quoted just after the 2004 elections as saying:

Regrettably, South Africa is populated with reactionary opposition parties that are perpetually bent on churning out destructive criticism. Opposition politics should ideally be to objectively partner with the government and help provide guidance in governing the country.

The minister ends her comments by saying:

The multitudes of South Africa have declared that no amount of sophistication or camouflage by the opposition can make them lose sight of their liberators.

Sunday Times 2 May 2004

This view of the opposition is pervasive in Southern Africa, where it is castigated as reactionary and delegitimised as lacking liberation credentials but at the same time is expected to be loyal. Evidence contained in an Afrobarometer 2004 survey suggests that support for opposition parties in the region has declined. The survey showed that more people in Southern Africa trust the ruling parties than the opposition. (Afrobarometer Working Paper No 34 2004). While this might be true in some cases, and certainly some opposition parties, referred to as 'briefcase parties', make their appearance only at election time, some of the expectations of what opposition parties should do and the yardsticks by which they are judged are unreasonable..

The growth of civil society overshadows the importance of opposition political parties, with civic organisations taking on the role of watchdogs of the government and citizens finding it beneficial to be members of such organisations rather than of political parties. The failure of the opposition to make an impact on policy issues makes it imperative for citizens to join interest-based civic organisations rather than political parties. It is also fashionable for middle-class citizens to be members of a civic organisation rather than of a political party and donors tend to give their assistance to NGOs and do not believe it is politically correct to confine their support to opposition parties. 
The result is that opposition parties generally find themselves competing with civic organisations for relevance. For example, in Zimbabwe there is rivalry between the National Constitutional Assembly (NCA), the Zimbabwe Congress of Trade Unions (ZCTU) and the opposition MDC, although the three occasionally support each other during strikes and demonstrations.

The opposition dilemma is highlighted by the situation in Zimbabwe, where the opposition is faced with the question 'to run or not to run' in an election and the problem of accepting elections results and thereby endorsing the legitimacy of the ruling party. The MDC challenged both the 2000 and 2002 election results. In the 2005 Senate election the MDC was split over whether to run or not and the faction which opted to run was heavily defeated. The dilemma of whether to run or not is a longstanding one in Zimbabwe where opposition parties are faced with an unfair electoral environment. In the 1995 election four parties - the Zimbabwe Unity Movement (ZUM), the United Parties (UP), and the Democratic Party (DP), and the new Zimbabwe African People's Union (Zapu) - boycotted the parliamentary elections, protesting against an uneven political playing field that favoured the ruling party while denying all other parties even a slight chance of winning (Makumbe \& Compagnon 2000, p 92).

In increasingly authoritarian environments such as the one that prevails in Zimbabwe the opposition is left with very little chance of democratising state and society. Not only has the struggle for power between the ruling Zimbabwe African National Union-Patriotic Front (Zanu-PF) party and the MDC polarised society, it has stalled the development of a democratic polity. Constrained by laws such as the Public Order and Security Act (Posa), which restricts association, and the Access to Information Protection and Privacy act (AIPPA), which gags the media, the opposition is left with very few options. The result is that it has pushed for constitutional reforms, which have not been addressed, and for electoral reforms, which have not been carried out (Sachikonye 2005, p 10). Although the presence of the opposition in Parliament means Zanu-PF's dominance is reduced the democratic space largely remains closed.

\section{IDEOLOGICAL DILEMMAS OF OPPOSITION PARTIES}

The national liberation parties in Southern Africa and their legacies continue to place constraints on policy development by emerging opposition parties. Academic attention has been paid to how the liberation legacy limits the consolidation of democracy in the region (Good 2002; Southall 2003) because of the clash between an authoritarian culture of national liberation and participatory democracy. However, there should be more regard for the ideological dilemmas these liberation legacies impose on opposition political parties. While ideological 
discontinuity is needed to maximise votes for the opposition, the new opposition parties, in their struggle for legitimacy, remain caught between the exigencies of the liberation ideology and their negated human rights and rule of law ideology.

The ideological shift to liberal democracy and the implementation of neoliberal economic policies has had both positive and negative outcomes. On the one hand it has led to the explosion of opposition politics and the end of the one-party state system in most countries in Southern Africa. On the other, the lack of alternatives to the neo-liberal agenda has deprived parties of the programmatic functions that can serve to mobilise supporters. Both the incumbents and the opposition have limited ideological choices in terms of fresh responses to economic policy changes; competition is therefore based on personalities and ethnic rivalries rather than on policies that will bring substantive change.

The forms of opposition political parties emerging on the back of civil society and the crisis of neo-liberal economic policies need to be further investigated. The opposition in both Zambia and Zimbabwe emerged out of economic crisis and the hardships faced by the working class. New social movements and the new opposition parties have challenged neo-liberal reforms, yet the same parties seek to implement market reforms once they are elected.

Decolonisation in Southern Africa brought to power anti-colonial liberation movements that took control of state machinery and established themselves as national political parties. The liberation struggle was also about rights and democracy. As Southall (2003) laments, the culture of the liberation struggle based on Leninist notions of vanguard leadership and democratic centralism has promoted a climate in which the opposition is regarded as illegitimate and reactionary. In the process the ideology of liberation has become entrenched, even in the new democracies of South Africa and Namibia.

'Once having attained national independence the inexorable logic of national liberation seems to be to suppress rather than to liberate democracy' (Southall, 2003, p 256). The role played by the liberation parties is even more important and far-reaching. Most of them, for instance, Zanu-PF in Zimbabwe and Frelimo in Mozambique, have created structures at the grassroots and created links with prominent personalities who have sustained forms of pervasive clientelism and patronage. The new opposition parties, with few links to the grassroots, find it difficult to break through these structures of loyalty, especially in the rural areas. The result is that the opposition becomes mainly an urban phenomenon springing from working-class disillusionment. The lack of ideological unity within new political movements such as the MDC in Zimbabwe and the MMD in Zambia has even led to splits among the founders of the parties and to a failure to break the hold of the nationalist legacy. 
The ideological dilemmas of opposition parties are clearly illustrated by Raftopoulos (2006) in a study of opposition politics in Zimbabwe in which he raises the specific challenges for the development of opposition politics in countries that have undergone an extensive liberation struggle. Since nationalist ideology requires resistance to neo-colonial and white domination and imperialism the supposed courtship between the elements of imperialism, that is, any relationship of the opposition with Western countries, is bound to provide positive ammunition for the ruling Zanu-PF. For example, the 'White Face' of the MDC has been heavily exploited by Zanu-PF both in the country and regionally (Raftopoulos 2006). Because of the MDC's affinity with the West it has been dismissed as an instrument of Western imperialism and a 'stooge' of the West.

In countries such as South Africa in which race is a thorny issue Mugabe's sentiments about the land issue and his racial attacks on British Prime Minister Tony Blair seem to have widespread support - he is regarded as a hero in South Africa while members of the MDC are regarded as sellouts. As Raftopoulos rightly points out (2006, p 25), Mugabe's Pan Africanist rhetorical stance causes problems for the MDC in the region and on the continent. Furthermore, one of the major weaknesses of the MDC has been its failure to develop an ideology that will enable it to have maximum control of its diverse supporters and to minimise conflict amongst its rural and urban supporters

The party sought support and legitimacy on the basis of the removal of Mugabe and of a human rights agenda that won the support of the West but did little to convince the rural population that it would put food on the table. The values of the MDC as the party of the people remain largely undefined, while Zanu-PF continues to fly the anti-colonial banner and marginalise the voices of democracy and human rights.

\section{OPPOSITION AND RULING PARTIES, THE PRACTICAL REALITIES}

The debate about the role of the party in government and the opposition continues, especially in a region that is endowed with dominant party systems. Southall (2001, p 5) presents the predicament of defining an opposition; a term which can either signify institutionalised opposition or refer to representation and acceptance of differences, or incorporate a range of anti-government behaviour. This predicament is exacerbated in South Africa where the opposition is inherently white. As Schmitz (1988, p 13) asserts, the government has a duty to govern and the opposition's right and duty in a parliamentary democracy is to oppose the government's policies and actions using every legitimate parliamentary means. Because the pervasive impact of colonialism, abject poverty, and political and cultural expediency informs the growth and the levels of stability of African 
political parties and party systems the notion of opposition in Africa is different from that which has developed over time in the West. Tony Leon, leader of the opposition Democratic Alliance in South Africa, has put forward the notion of opposition he believes is promoted by African governments: 'that to oppose the government of the day was to oppose nation building and that to engage in political disputes was to make an enemy of patriotism' (The Star (Johannesburg) 30 June 2006).

The relationship between ruling parties and their opposition is marked by tension and conflict that stem from the nature of their respective roles. The tension may produce a healthy and productive engagement, as in South Africa where the opposition DA points out every limitation of government policy and the ANC government takes up the challenge by trying to provide solutions.

However, in some cases, such as that of Zimbabwe, the tensions can lead to destructive and violent engagement, as was the case with Zanu-PF and the MDC in the run-up to the 2000 parliamentary and 2002 presidential elections. Normally ruling parties clash with the most threatening opposition party, as was the case in the Zanzibar elections in 2005 when the ruling Chama cha Mapinduzi (CCM) came into conflict with the opposition Civic United Front (CUF). Violent clashes have also taken place between Frelimo and Renamo in some provinces in Mozambique.

\section{THE ADVANTAGES OF INCUMBENCY}

There is a huge difference between opposition parties and ruling parties in Africa. The ruling parties, especially the dominant ones, are confident and powerful and have government resources at their disposal, especially in Southern Africa where the line between the government and the ruling party is blurred. The ruling party, by virtue of its monopoly of the government structures, has a major advantage. The president of the party is usually in charge. He or she decides when elections will be held and can use events such as opening a new clinic or school, the provision of houses to the poor, or the rolling out of the much needed antiretroviral drugs to launch a campaign.

The leader of the opposition, on the other hand, finds it hard to get publicity and, if he or she does get any, it is probably negative. Even in a country such as South Africa with a relatively democratic outlook the opposition has complained about the politically biased and disproportionate coverage of the ruling party by the public broadcaster in the most recent elections (Lodge and Scheidegger 2006, p 6). Similarly, in Zambia the MMD has abused the Zambia National Broadcasting Corporation and the state-owned print media, the Times of Zambia, the Daily Mail, and the Sunday Times. The EU mission and other local observer groups made 
reference to this misuse of state resources in the 2001 elections (Momba 2005, p 7). Even in established democracies such as Mauritius complaints about the use and abuse of public resources were among the first statements made to observer missions by the opposition Alliance Sociale. The life of an opposition leader is frequently made miserable by harassment and even imprisonment, as is the case in Zimbabwe.

The dominance of African political parties can be explained by the fact that they developed outside of the parliamentary framework during the struggle for political emancipation and became instruments or institutional mechanisms for the transition to democracy (Salih 2003, p 6). The legitimacy of parties such as the South West African People's Organisation (Swapo) in Namibia, Frelimo, ZanuPF, the African National Congress (ANC) and the CCM in Tanzania resonates within the liberation struggle. Although some of these parties became governing parties with small majorities they have developed over time into dominant parties, gaining increasing numbers of votes at each election.

While the process of one-party dominance has created strong mass-based parties on the one hand, it has resulted in weak and fragmented opposition parties on the other.

\section{OPPOSITION PARTIES}

The political landscape of Southern Africa is littered with parties of different sizes, strengths and levels of acceptability. However, regional institutions such as the Southern African Development Community (SADC) have not played their part in ensuring a place for opposition parties in their deliberations pertaining to governance and economic development. SADC has been criticised for its lack of inclusion of civil society and opposition political parties. The organisation has been accused of operating under the false assumption that present ruling parties will govern indefinitely, and succession issues are not taken into account (ISS Report 2005, p 12). Opposition parties are now visible in all Southern African one-party dominant parliaments except for that of Swaziland, the region's only absolute monarchy (see Table 1).

Swaziland's new Constitution is ambiguous, allowing for certain freedoms and no longer banning political parties. However, the king remains convinced that the country is not yet ready for political parties and parties such as People's United Democratic Movement (Pudemo) and other opposition groups are alleged to have been responsible for violent bombings (IRIN News 29 June 2006). The monarchy has demonised party politics over the years and most Swazis seem to have opted for the monarchy, with opposition parties becoming underground movements that are constantly persecuted (Mzizi 2005, p 3). 
Multipartyism was instituted in the early 1990s in most of the former oneparty states such as Tanzania, Zambia and Mozambique but the level of institutionalisation of opposition parties remains tenuous and inchoate and most of them are products of the splits, factionalism and power struggles within the former liberation movements.

In Tanzania, for instance, the one-party state culture was so entrenched that, in a referendum 80 per cent of voters voted for such a state, with only 20 per cent opting for multiparty democracy (Shayo 2005, p 7). This absence of belief in the value of a multiplicity of parties may well still be present in other former oneparty state systems.

Table 1 shows the prevalence of opposition parties in Southern Africa and also their share of seats. The official opposition has the bulk of the seats and a few remaining seats are split between a number of smaller opposition parties. The official opposition parties in Southern Africa, based on the most recent elections, are Unita, the former rebel movement in Angola, and the Botwsana National Front (BNF) in Botswana, which is accused of playing big brother to the other smaller parties and which fails to maintain any coalitions or alliances. The Basotho National Party (BNP) is the official opposition in Lesotho and in Mauritius the former party in power, the Mouvement Militant Socialiste Mauricien/ Mouvement Militant Mauricien (MSM/MMM) is now in opposition. Mauritius has a history of the alternation of parties or coalitions in power. Renamo, the former rebel movement, is the official opposition in Mozambique. In Malawi parties are in crisis, with 39 independent candidates having contested the 2004 elections. While independents can compete in elections in a pluralistic society such prevalence is a sign of disillusionment with the quality of existing parties. The political party crisis in Malawi was exacerbated when President Bingu Wa Mutharika, who was elected on a UDF party ticket in 2004, resigned from the party and formed a new one, called the Democratic Progressive Party (DPP). The newly formed party now boasts more than half the 193 MPs in the Malawian Parliament as most of the independents and the other parties crossed over to join the president's new party. The splits, counter-splits and realignments in Malawian politics undermine the entire party system and the credibility of opposition politics. Even taking into consideration the intensity of ethnic cleavages and the nature of the electoral system in Southern Africa, the party system tends to lean towards a strong duopoly. Most regional or ethnic parties tend to be weak electorally and to be single-issue parties. With the development of party coalitions and alliances there is the probability that the region may move over to a more stable two-and-a-half-party system. It is also advisable for opposition parties to form coalitions in order to ensure legislative effectiveness in a region of oneparty dominance. 
Table 1

Opposition Parties in Southern African Legislatures

\begin{tabular}{|c|c|c|c|c|}
\hline Country & Election year & $\begin{array}{l}\text { Opposition parties } \\
\text { in the legislature }\end{array}$ & $\begin{array}{c}\text { Electoral } \\
\text { system }\end{array}$ & $\begin{array}{l}\text { No of } \\
\text { seats }\end{array}$ \\
\hline \multirow[t]{5}{*}{ Angola } & 1992 & Unita & PR & 70 \\
\hline & & FNLA & & 5 \\
\hline & & PLD & & 3 \\
\hline & & PRS & & 6 \\
\hline & & $\begin{array}{l}\text { PRD, AD, PSD, PAJOCA, } \\
\text { FDA, PDP-ANA, PNDA }\end{array}$ & & 1 seat each \\
\hline \multirow[t]{2}{*}{ Botswana } & 2004 & BNF & FPTP & 12 \\
\hline & & $\mathrm{BCP}$ & & 1 \\
\hline DRC & 2006 & - & FPTP & - \\
\hline \multirow[t]{6}{*}{ Lesotho } & 2002 & BNP & MMP & 21 \\
\hline & & BAC & & 3 \\
\hline & & $\mathrm{BCP}$ & & 3 \\
\hline & & LPC & & 5 \\
\hline & & NIP & & 5 \\
\hline & & LWP, MFP, PFD, NPP & & 1 seat each \\
\hline \multirow[t]{8}{*}{ Malawi* } & 2004 & UDF & FPTP & 50 \\
\hline & & $\mathrm{RP}$ & & 15 \\
\hline & & $\mathrm{NDA}$ & & 8 \\
\hline & & Aford & & 6 \\
\hline & & PPM & & 6 \\
\hline & & Mgode & & 3 \\
\hline & & Conu & & 1 \\
\hline & & Petra & & 1 \\
\hline Mauritius & 2005 & $\begin{array}{l}\text { MSM/MMM } \\
\text { OPR }\end{array}$ & Mixed & $\begin{array}{r}22 \\
2\end{array}$ \\
\hline Mozambique & 2004 & Renamo & PR & 90 \\
\hline
\end{tabular}




\begin{tabular}{|c|c|c|c|c|}
\hline \multirow[t]{6}{*}{ Namibia } & 2004 & DTA & PR & 4 \\
\hline & & UDF & & 3 \\
\hline & & MAG & & 1 \\
\hline & & $\mathrm{CoD}$ & & 5 \\
\hline & & Nudo & & 3 \\
\hline & & RP & & 1 \\
\hline Seychelles & 2002 & SNP & Mixed & 11 \\
\hline \multirow[t]{6}{*}{ South Africa } & 2004 & DA & PR & 50 \\
\hline & & IFP & & 28 \\
\hline & & UDM & & 9 \\
\hline & & ID & & 7 \\
\hline & & ACDP & & 7 \\
\hline & & NNP & & 7 \\
\hline Swaziland & 2003 & 0 & FPTP & 0 \\
\hline \multirow[t]{4}{*}{ Tanzania } & 2005 & CUF & & 30 \\
\hline & & Chadema & & 11 \\
\hline & & TLP & & 1 \\
\hline & & UDP & & 1 \\
\hline \multirow[t]{6}{*}{ Zambia } & 2001 & UPND & FPTP & 43 \\
\hline & & FDD & & 12 \\
\hline & & UNIP & & 13 \\
\hline & & Heritage Party & & 2 \\
\hline & & Patriotic Front & & 2 \\
\hline & & Zambia Republican Party & & 1 \\
\hline \multirow[t]{2}{*}{ Zimbabwe } & 2005 & MDC & & \\
\hline & & FPTP & & 41 \\
\hline
\end{tabular}


Each country is unique in the way opposition parties have grown. Some grew out of civil war and conflicts, as in Angola and Mozambique, where there are more than 30 or 40 registered parties, only a few of them represented in the legislature. In countries with a proportional representation (PR) electoral system (Angola, Mozambique, Namibia, South Africa) there more parties are represented in the legislature, confirming the argument that PR is more inclusive and allows for the growth and survival of opposition parties, though it says nothing about legislative effectiveness. After its 1992 election Angola had 11 opposition parties in the legislature - some of them with only one seat, suggesting that they are based on minority interests, mostly ethnic. This also suggests a very unstable party system, with parties involved either in coalitions or formed as a result of splits resulting from power struggles.

Lesotho boasts nine opposition parties in the legislature, attributable to the introduction of the mixed member proportional (MMP) electoral system. However, fragmentation and factionalism still impede the development of viable opposition parties in the country. Most of the factional fights among the opposition parties are caused not as much by ideological or policy tensions as by personality differences, leadership tussles, and scuffles (Matlosa and Sello 2005, p 4) Parties in Lesotho, although they have limited resources, have tried to subscribe to broadly defined party-based democratic principles such as intra-party democracy, being mindful of gender balance. However, sustaining a culture of democracy, tolerance and constructive management of political conflicts remains a challenge to the consolidation of Lesotho's democracy (Matlosa and Sello 2005, p 51).

South Africa and Namibia boast a free political environment which allows for the flourishing of opposition parties. Serious disagreements in Swapo over the third term led to the formation of the Congress of Democrats (CoD), but instead of the CoD garnering support from Swapo members in the 1999 elections, Swapo won two extra seats. All seven seats won by the $\mathrm{CoD}$ came from another opposition party, the Democratic Turnhalle Alliance (DTA) rather than from Swapo (Tonchi \& Shifotoka 2005, p 10), another example of a situation where, when the opposition fragments, the dominant party gains at its expense.

\section{THE VISIBILITY OF OPPOSITION PARTIES IN SOUTHERN AFRICA}

Although opposition parties in Southern Africa are quite visible (see Table 2), their viability and effectiveness in governance remain questionable. The proliferation of opposition parties and the constant fragmentation does not reflect the success of multipartyism or the consolidation of democracy. However, South Africa, which achieved majority rule in 1994, is regarded as having a 'long established group of political parties ... which become more predisposed to accept 
the legitimacy of each other's activities and are beginning to constitute a party system' (Lodge and Scheidegger 2005, p 37). Much credit is given to South Africa's proportional representation (PR) system, which has enabled inclusiveness.

Although the ANC has dominated since 1994 (see Table 3), gaining more seats at every election, weakened opposition representation in the National Assembly has not, thus far, undermined democracy in the country. This does not mean that the opposition has not been vocal in demanding government accountability. The political environment in South Africa is such that opposition parties are free to operate and associate. As a result, even when the opposition

Table 2

Ruling and Opposition Parties Share of Seats in Southern Africa

\begin{tabular}{|l|c|l|c|c|c|c|c|}
\hline Country & $\begin{array}{c}\text { Last } \\
\text { election } \\
\text { date }\end{array}$ & $\begin{array}{c}\text { Electoral } \\
\text { system }\end{array}$ & $\begin{array}{c}\text { Size } \\
\text { of } \\
\text { legislature }\end{array}$ & $\begin{array}{c}\text { No of } \\
\text { ruling } \\
\text { party seats }\end{array}$ & $\begin{array}{c}\text { Opposition } \\
\text { parties in } \\
\text { legislature }\end{array}$ & $\begin{array}{c}\text { Share of } \\
\text { opposition } \\
\text { seats }\end{array}$ & $\begin{array}{c}\text { Appointed } \\
\text { seats }\end{array}$ \\
\hline Angola & 1992 & PR & 220 & 129 & $\mathbf{1 1}$ & 101 & 0 \\
\hline Botswana & 2004 & FPTP & 57 & 44 & $\mathbf{2}$ & 13 & 7 \\
\hline DRC & - & FPTP & 500 & - & - & - & - \\
\hline Lesotho & 2002 & MMP & 120 & 77 & $\mathbf{9}$ & 41 & 0 \\
\hline Malawi & 2004 & FPTP & 192 & 57 & $\mathbf{9}$ & & \\
\hline Mauritius & 2005 & Mixed & 70 & 38 & $\mathbf{2}$ & 22 & 8 \\
\hline Mozambique & 2004 & PR & 250 & 160 & $\mathbf{1}$ & 90 & 0 \\
\hline Namibia & 2004 & PR & 72 & 55 & $\mathbf{6}$ & 17 & 6 \\
\hline Seychelles & 2002 & Mixed & 34 & 23 & $\mathbf{1}$ & 11 & 9 \\
\hline South Africa & 2004 & PR & 400 & 279 & $\mathbf{6}$ & 108 & 0 \\
\hline Swaziland & & FPTP & 85 & - & $\mathbf{0}$ & 0 & 0 \\
\hline Tanzania & 2005 & FPTP & 323 & 264 & $\mathbf{4}$ & 44 & 42 \\
\hline Zambia & 2001 & FPTP & 158 & 76 & $\mathbf{6}$ & 74 & 8 \\
\hline Zimbabwe & 2005 & FPTP & 150 & 78 & $\mathbf{1} * *$ & 41 & 30 \\
\hline
\end{tabular}

Source: adapted from Matlosa 2003, p19

* Zambia has one independent in Parliament

** In Zimbabwe the other representative in Parliament is an independent 
has experienced losses at the polls the results have been acceptable to all the parties and no opposition party has seriously contested the outcomes of national elections.

This cannot be said about opposition parties in other parts of the region. In Zimbabwe, for example, although the MDC has 41 seats in the legislature it cannot proudly say that it has been effective. The continuing economic and governance crisis in the country is a manifestation of the lack of consensus between the opposition and the ruling party on the rules governing the Zimbabwean polity.

\section{ONE-PARTY DOMINANCE AND OPPOSITION FRAGMENTATION}

In a dominant-party system opposition parties in Southern Africa have to overcome three obstacles in their battle for visibility and effectiveness: institutional and structural barriers to political visibility; the fight for the hearts and minds of the electorate, which is largely comfortable with the devil it knows; and the fight to maintain a constant flow of resources and membership, since most opposition parties are not publicly funded.

The result is that most of the opposition in the region, whether in PR or FPTP electoral systems remains weak and splintered. In the new democracies of South Africa and Namibia the opposition is still split along racial, ethnic and regional lines and the ruling parties dominate (see Tables $3 \& 4$ ). Even in Botswana, one of the oldest democracies on the continent, where elections are mostly pronounced free and fair, the opposition is fragmented and continues to split votes, further reducing the opportunity for a viable opposition in Parliament. Only in the 1994 elections did the opposition BNF really threaten the ruling Botwsana Democratic Party (BDP) in Botswana when it won the 13 seats to the BDP's 27 (Somolekae 2005, p 10). However, in the 2004 elections the ruling BDP maintained its dominance, with 44 seats in the legislature to the BNF's 12. The reasons for one-party dominance have been well documented and range from a weak opposition to the sociopolitical structures of Southern African countries.

\section{THE DOMINANCE OF THE ANC IN SOUTH AFRICA}

South Africa is a special case that illustrates the importance of national liberation ideology, the charisma of liberation heroes such as Nelson Mandela, and ethnic and racial divisions as powerful determinants of voting patterns. Loyalty to the ANC as the people's liberators still runs deep so that while disenchantment with the ANC government has grown, as exemplified by the working-class township protest over issues of service delivery, the ANC still won 65 per cent of the vote in the March 2006 local government elections. Furthermore, the near two-thirds 
Table 3

South Africa: Allocation of Parliamentary Seats 1994-2004

\begin{tabular}{|l|c|c|c|}
\hline Party & $\mathbf{1 9 9 4}$ & $\mathbf{1 9 9 9}$ & $\mathbf{2 0 0 4}$ \\
\hline ANC & 252 & 266 & 279 \\
\hline DA & 7 & 38 & 50 \\
\hline IFP & 43 & 34 & 28 \\
\hline UDM & - & 14 & 9 \\
\hline ID & - & - & 7 \\
\hline ACDP & 2 & 6 & 7 \\
\hline NNP & 82 & 28 & 7 \\
\hline
\end{tabular}

majority of 279 in the national elections in 2004 shows that ANC dominance is far from threatened.

Opposition parties in South Africa have failed to attract significant support from black voters. As Table 3 shows, between 1994 and 2004 the ANC lost no seats, in fact it gained them as the opposition lost them. It also benefited from floor crossing. The Inkatha Freedom Party (IFP), which was transformed from an ethnic Zulu cultural movement into a political party, has continued to lose seats since 1994 while parties such as the Independent Democrats (ID) and the United Democratic Movement (UDM) are largely regional. The Democratic Alliance continues to gain seats from other opposition parties but fails to attract black membership.

The only credible opposition is expected to emerge should the tripartite alliance between the ANC, the Congress of South African Trade Unions (Cosatu) and the South African Communist Party (SACP) break up. Most of Cosatu's leaders have been absorbed into government, leaving the movement with a weak leadership similar to that of the Zimbabwe Congress of Trade Unions (ZCTU), whose leadership entered party politics via the MDC. Within the alliance, the SACP and Cosatu provide the intellectual arguments for the Left. President Thabo Mbeki has been criticised for 'talking left and acting right', while the hopes engendered by liberation have given way to free market neoliberal policies that are believed to have left the vast majority of South Africans in the grip of poverty, unemployment and social crisis (Bond 2004).

Tensions among the ANC, the SACP and Cosatu have mounted in recent 
years as the ANC's partners have demanded a voice in policy-making and have criticised the government's stance on economic policy, labour reform and privatisation. These divisions have been exacerbated by the ongoing power struggle between former deputy president Jacob Zuma and Thabo Mbeki, which has brought to the fore the succession debate. Some believe they offer the Left a unique opportunity to forge greater unity and aid the movement towards the formation of a mass-based workers' party. Currently, however, the alliance has held and hopes of a left-wing opposition party remain a remote dream.

Opposition parties are still judged according to how well they present a challenge to the ANC. In fact, the focus should shift from removal of the incumbents to how successfully the parties are articulating their opposition role, which is to speak on behalf of the minority and to keep government accountable. This role cannot be fulfilled if the opposition does not comprehend and fully accept it and if it does not have the support of the populace. Opposition parties should move away from a concept of governance which is concerned only with capturing state power and concentrate on democratising their structures as well as society.

Table 4

Political Party Representation in the Namibian National Assembly 1989-2004

\begin{tabular}{|l|c|c|c|c|}
\hline Party & $\mathbf{1 9 8 9}$ & $\mathbf{1 9 9 4}$ & $\mathbf{1 9 9 9}$ & $\mathbf{2 0 0 4}$ \\
\hline SWAPO & 41 & 53 & 55 & 55 \\
\hline DTA & 21 & 15 & 7 & 4 \\
\hline UDF & 4 & 2 & 2 & 3 \\
\hline ACN/MAG & 3 & 1 & 1 & 1 \\
\hline FCN & 1 & 0 & 0 & 0 \\
\hline NNF & 1 & 0 & 0 & 0 \\
\hline NPF/DCN & 1 & 1 & 0 & - \\
\hline CoD & - & - & 7 & 5 \\
\hline Nudo & - & - & 0 & 3 \\
\hline RP & - & - & 0 & 1 \\
\hline Total & 72 & 72 & 72 & 72 \\
\hline
\end{tabular}

Source: Tonchi \& Shifotoka 2005, p 18 
The Namibian case illustrates how opposition parties are created out of disagreements within the ruling party. The CoD was formed in 1999 as an alternative to Swapo because the ruling party had failed to bring about significant development since the country's independence. But the party miscalculated its popularity, winning only seven seats in the first election in which it stood, not from Swapo but from the official opposition, the DTA, which had won 15 seats in 1994. This suggests that the formation of a new party further fragments and weakens the opposition. Such a situation is not unique to Namibia, it is true of most countries in Southern Africa. Both the National Unity Democratic Party (Nudo) and the Republican Party (RP) seem to have won their seats in the 2004 election from the $\mathrm{CoD}$, which lost two, while Swapo maintained its 55 seats. These figures demonstrate clearly how opposition fragmentation benefits the ruling party.

\section{IS OPPOSITION UNITY A MYTH?}

Can opposition alliances be sustained merely by the parties being united as members of the opposition or is something more substantive than 'throwing the rascals out of government' needed in order to foster opposition unity and success? Whether their co-operation is called alliances, opposition unity or coalition, the opposition in countries like Mozambique, Botswana, Mauritius and Zambia have recently joined in order to challenge the incumbents. In Zambia three opposition parties - the Forum for Democracy and Development (FDD), The United Party for National Development (UPND), and the UNIP - have formed an alliance called the United Democratic Alliance (UDA) to fight the 2006 elections (One World Radio 2006). The alliance's aim is to remove the MMD government. Whether it succeeds either as an alliance or in its central aim remains to be seen.

Alliances are increasingly being considered the solution to weak and fragmented opposition political parties. Some of them work as, for instance, in Mauritius, which has a history of coalition government, but in countries such as Botswana the alliances collapse before they are even tried and tested by the electorate.

In Botswana the issue of political party unity emerged in 1989. There have been several attempts at party cooperation pacts and mergers, without much success. Since 1991 attempts at party unity have been made through structures such as the People's Progressive Front (PPF) and the Botswana Alliance Movement in 1998 and several others are in the pipeline (Somolekae 2005, pp 13-15). The merging of opposition parties is becoming the new strategy for strengthening them. However there is a danger that loosely organised coalitions assembled for electoral purposes will collapse soon after losing the election. 


\section{SUPPORTING THE PARTY SYSTEM}

The international community has been promoting multiparty democracy by offering political party assistance programmes. Many democracy foundations and organisations such as the International Institute for Democracy and Electoral Assistance (IDEA) and EISA are working on projects and programmes to support the development of inclusive electoral systems and effective party systems.

The United Nations Development Program (UNDP) and organisations such as the National Democratic Institute for International Affairs, (NDI), the United States Agency for International Development (USAID), and the Netherlands Institute for Multiparty Democracy (IMD), together with some German foundations, fund political parties in promoting core democratic values (Kumar 2004, p 6). However, there should be an emphasis on supporting opposition parties. Regional and international meetings have been organised to bring both ruling and opposition parties together to copy best practice from other countries.

Different approaches are being used to bring the parties together in interparty dialogues to discuss issues and goals that advance democracy. All parties have openly debated issues such as electoral system reforms, the increased representation of women, and the public funding of political parties in countries such as Botswana and Mauritius. ${ }^{1}$

The support of the electorate for the party system is absolutely crucial to democracy as it is they who must be content with the opposition. If stable and organisationally sound opposition parties are created without the support of the populace a democratic deficit remains. The opposition and the electorate must be properly located within the governance debate in Southern Africa.

While financial support for opposition political parties is crucial for the growth of mature democracies, there are positive and negative consequences of donors funding opposition politics. The reality is that in Southern Africa opposition and civic organisations depend heavily on donor funding. International funding for parties comes in different forms - for organisational development, election campaigns, the training of women candidates, multiparty collaboration, technical assistance, seminars, workshops, and meetings. Most parties in the region are funded in this way but will not disclose either the extent of the funding or the names of the donors. Although such assistance is necessary in a region that is poor and where the ruling parties have access to state resources and most parties

\footnotetext{
An All-Party Conference organised by EISA and IDEA was held in Mauritius on 17-18 February 2006 to discuss an inclusive democracy in the country, which included lobbying the government for electoral reforms. In Botswana a stakeholder conference was held on 13-15 March to discuss electoral reforms and the funding of political parties and increased gender representation in all political parties.
} 
are not publicly funded, ruling parties tend to be suspicious of funding of opposition parties and parties which do not receive assistance resent those that do.

There is a strong belief that foreign powers should not engage in activities that directly or indirectly affect the outcome of elections. A related issue concerns the partisanship shown by some international donors to one or a few political parties (Kumar 2004, p 24). Such partisanship tends to be problematic as it blurs the distinction between assistance and political manipulation.

The problems of dependence on foreign funding arise when the recipients agitate for what appear to be foreign agendas. There is no guarantee that the agendas are in the interests of the citizens and the opposition and civic organisations appear to emphasise abstract issues rather than the day-to-day problems that affect society. The fact that the recipient parties are accountable to the donor and not the citizens leaves room for parties to abuse the funds or to be corrupt, without other, parallel, forms of accountability.

Despite these reservations, it is of paramount importance that opposition parties are funded, and mechanisms for accountability should be developed as well as criteria for who to fund and which areas of activity. At present civil society organisations appear to receive the bulk of the funding at the expense of fragile and needy opposition parties.

\section{CONCLUSION}

This paper has attempted to set out the dilemmas of opposition political parties, which include their being obscured in the governance debate by being lumped together; being neglected by donors and by voters; negative perceptions; and having to deal with the power of incumbency while continuing to keep government accountable. Opposition parties remain threatened by other civic organisations and most of all by the dominant parties. In Southern Africa they have to deal with a range of political systems - some more open, others entirely closed. One common factor, though, is the public perception of relative weakness and of opposition parties not being able to mount a successful challenge to incumbents.

The dilemmas the opposition faces in its day-to-day operations are not merely academic, they are practical realities. Much opposition is lame and the dominant ruling party remains a challenge. Nonetheless, the spread of democratisation has enabled most opposition parties to demand and create an environment in which they can organise and function freely. The process of registering political parties has been simplified in most countries in the region, except Swaziland.

In terms of internal party democracy most opposition parties in the region are striving for decentralised structures, but there is great variation in their capacity 
to function effectively. The responsibility lies with Southern Africans to be prepared to work with opposition parties. The focus should move away from organisations waiting to capture state power and explore ways of maintaining and building party organisations that are democratic, representative, and serve democracy appropriately between elections. The opposition must realise that it takes years, and adequate resources, to be fully institutionalised and to find roots in society. Institutionalisation depends on the way the opposition is organised as an instrument for mobilising support. The future of democracy in Southern Africa lies with opposition political parties that are well-organised, democratic, gender balanced and active.

\section{- REFERENCES —}

Bratton, Michael, Carolyn Logan, Wonbin Cho and Paloma Bauer. 2004. Afrobarometer Round 2 Compendium of Comparative Results from a 15-country survey. Afrobarometer Working Paper No 34, 2004

Bond, Patrick. 2004. 'Ten years after the fall of apartheid'. Socialist Worker on line. http: / / www.socialistworker.org/2004-1/498/498_05_Bond.shtml

EISA. 2005. Election Observer Mission Report No 20. Tanzania Presidential National Assembly and Local Government Elections, 14 December.

Good, Kenneth. 2002. The Liberal Model and Africa: Elites against Democracy. London: Palgrave.

Hout Wil. 2003. 'Political Parties and Governance'. In MA Mohamed Salih (ed). African Political Parties Evolution, Institutionalisation and Governance. London: Pluto Press.

ISS Conference Report. 2005. Policy Research and Capacity Building in Southern Africa, 1-2 December.

Kumar, Krishna. 2004. International Party Assistance: An Overview and Analysis. Working Paper 33. Netherlands Institute of International Relations, Conflict research Unit, October.

Lavelle, Ashley. 2004. Paper given at the Opposition Round Table. www.parliamentstudies.anu.edu.au

Lodge, Tom \& Ursula Scheidegger. 2006. Political Parties and Democratic Governance in South Africa. EISA Research Report No 25.

Makumbe, John M \& Daniel Compagnon. 2000. Behind the Smokescreen: The Politics of Zimbabwe's 1995 General Elections. University of Zimbabwe Publications. Matlosa, Khabele \& Caleb Sello. 2005. Political Parties and Democratisation in Lesotho. EISA Research Report No 23.

Momba, Jotham. 2005. Political Parties and the Quest for Democratic Consolidation in Zambia. EISA Research Report No 17. 
Mzizi, Joshua Bheki. 2005. Political Movements and the Challenges for Democracy in Swaziland. EISA Research Report No 18.

Patel, Nandini. 2005. Political Parties: Development and Change in Malawi. EISA Research Report No 21.

One World Radio. 2006. 'Zambia's three opposition parties merge', 26 June. http: / / radio.oneworld.net/article/view/83331/1

Randall, Vicky \& Lars Svasand. 2002. 'The Contribution of Parties to Democracy and Democratic Consolidation'. Democratisation 9(3).

-2002. 'Political Parties and Democratic Consolidation in Africa'. Democratisation 9(3).

Raftopoulos, Brian and K Alexander. 2006. Reflections on Democratic Politics in Zimbabwe. Cape Town: Institute for Justice and Reconciliation.

Sachikonye, Lloyd. 2005. Political Parties and the Democratisation Process in Zimbabwe. EISA Research Report No 16.

Salih, Mohamed M A. 2003. 'The Evolution of African Political Parties'. In M A Mahamed Salih (ed). African Political Parties: Evolution, Institutionalisation and Governance. 2005. Globalized Party Democracy and Africa: The Influence of Global Party Based Democracy Networks. CSGR Working Paper No 173/05 August www.csgr.org

Schmitz, Gerald. 1988. The Opposition in a Parliamentary System. Political and Social Affairs Division, Library of Parliament. www.parl.gc.ca/information/ library / PRBpubs / bp47-e.htm

Shayo, Rose. 2005. Political Parties and Political Development in Tanzania. EISA Research Report No 24.

Somolekae, Gloria. 2005. Political Parties in Botswana. EISA Research Report No 27. Southall, Roger (ed). 2001. Opposition in South Africa: Issues and Problems In Opposition and Democracy in South Africa. London: Frank Cass.

—. 2003. 'Democracy in Southern Africa moving beyond a difficult legacy'. Review of African Political Economy 96.

Tonchi, L Victor \& Albertina N Shifotoka. 2005. Parties and Political Development in Namibia. EISA Research Report No 26.

Tucker, Peter. 2005. 'Winning Government from Opposition: Has Colin Barnett got a clue?', 15 February http://www.onlineopinion.com.au/view.asp/ article.

United Kingdom Parliament. 2006. Government and Opposition, 19 June. www.uk/ works/pagovopp.cfm

Van Cranenburgh, Oda. 2003. 'Power and Competition: The Institutional Context Of African Multi Party Politics'. In MA Mohamed Salih (ed). African Political Parties Evolution, Institutionalisation and Governance. London: Pluto Press.

Venter, Denis. 2003. 'Multiparty Politics and Elections in Southern Africa: Realities 
and Imageries'. In MA Mohamed Salih (ed). African Political Parties Evolution, Institutionalisation and Governance. London: Pluto Press.

Webb, Paul. 2005. 'Political Parties and Democracy: The Ambiguous Crisis'. Democratisation 12(5), December.

Zimbabwe Election Support Network. 2005. Results of the 2005 Senate Elections and Gutu North Parliamentary By-election. Report, November. 